\title{
The Impact of the $\mathrm{Ug}_{\max }$ Soil Fertilizer on the Presence of Streptomyces Scabies on Edible Potato Tubers
}

\author{
Alicja Baranowska'", Krystyna Zarzecka², Marek Gugała², Iwona Mystkowska' \\ 1 Institute of Agriculture, Pope John II State School of Higher Education in Biala Podlaska, Sidorska 95/98, \\ 21-500 Biała Podlaska, Poland \\ 2 Department of Agrotechnology, University of Natural Sciences and Humanities in Siedlce, B. Prusa 14, $08-$ \\ 110 Siedlce, Poland \\ * Corresponding author's e-mail: alabar@tlen.pl
}

\begin{abstract}
The purpose of the three-year-long field experiment was to identify the effect of the $\mathrm{UG}_{\max }$ soil fertilizer (microbiological preparation) on the presence of Streptomyces scabies on tubers of two edible potato cultivars. The experiment was established using the randomized split-block method, in three replications, in central Poland $\left(52^{\circ} 03^{\prime} \mathrm{N} ; 22^{\circ} 3^{\prime} \mathrm{E}\right)$, on the soil consisting of loamy sands, slightly acidic and acidic. The examined factors included: 1st factor: edible potato cultivars (Satina and Typhoon), 2nd factor: doses and dates of application of the $\mathrm{U}_{\mathrm{Gmax}}$ soil fertilizer (1. control object without $\mathrm{UG}_{\max } ; 2 . \mathrm{UG}_{\max }$ applied to soil before planting tubers at a dose of $1.0 \mathrm{dm}^{3} \cdot \mathrm{ha}^{-1} ; 3 . \mathrm{UG}_{\max }$ applied to soil before planting tubers at a dose of $0.5 \mathrm{dm}^{3} \cdot \mathrm{ha}^{-1}$, when the height of plants is about $10-15 \mathrm{~cm}$, and in the flower buds making phase at a dose of $0.25 \mathrm{dm}^{3} \cdot \mathrm{ha}^{-1} ; 4 . \mathrm{UG}_{\max }$ before planting tubers at a dose of $1.0 \mathrm{dm}^{3} \cdot \mathrm{ha}^{-1}$ and when the height of plants is about $10-15 \mathrm{~cm}$, and in the flower buds making phase at a dose of $0.5 \mathrm{dm}^{3} \cdot \mathrm{ha}^{-1} ; 5 . \mathrm{UG}_{\max }$ when the height of plants is about $10-15 \mathrm{~cm}$, and in the flower buds making phase at a dose of $0.5 \mathrm{dm}^{3} \cdot \mathrm{ha}^{-1}$ ). Symptoms of common scab were assessed on a 9-point scale on 100 tubers randomly collected from different experiment objects. As a result of the study, it was demonstrated that treatments with the use of the $\mathrm{UG}_{\max }$ soil fertilizer limited the occurrence of common scab on potato tubers and affected the average level of infestation of the sample and the average level of infestation of infested tubers.
\end{abstract}

Keywords: Solanum tuberosum L., common scab, microbiological preparation

\section{INTRODUCTION}

In the agriculture of the $21^{\text {st }}$ century, modern production methods, not only influencing the size and quality of yields, but also enabling restoration of the soil's biological activity, are sought. The production of plants uses various kinds of soil fertilizers, microbiological preparations, improving the properties of the soil environment as well as the health condition and plant resistance to stress. These trends are also visible in the agrotechnics of potato (Solanum tuberosum L.), which is one of the most commonly cultivated plants, determining the capacity to feed the world's population [Homuz et al., 2010; Kowalska, 2016; Zarzecka et al., 2016; Baranowska et al., 2017].

Solanum tuberosum L. is a plant that is difficult to cultivate. The vegetative manner of repro- duction causes potato plantations to be exposed to dangerous bacterial, viral and fungal diseases. Pathogens are often transferred along with seed potatoes, constituting the source of infections in the new plantation. One of the most dangerous bacterial diseases appearing in all areas of potato cultivation in the world is the common scab (Streptomyces scabies (Thaxter) [Loria et al., 2003, 2006]. The disease is caused by actinomycetes of the Streptomyces genus, mainly Streptomyces scabies (a synonym of $S$. scabiei) [Lerat et al., 2009; Chater et al., 2010].

The pathogen infests tubers during the vegetation period. Bacteria penetrate tubers through lenticels, stoma, as well as epidermis and periderm. The infested tubers react by creating a barrier around the damaged area (cork layers) [Loria et al., 1997, 2008; Tegg et al., 2008; Borodynko 
et al., 2016]. Brown cork-like callosities appear on tubers, which reduce the consumer value and eliminate potatoes from commercial trade [Atiq et al., 2013; Leiminger et al., 2013;]. The development of the disease is fostered mainly by cultivating potatoes on soils with $\mathrm{pH}>5.6$, frequent liming of soil, high temperatures, and lack of precipitation in the period of tuber forming [Waterer, 2002; Wróbel, 2003; Borodynko et al., 2016].

Despite the growing interest of science and agricultural practice in various kinds of preparations and soil fertilizers improving the health condition and plant resistance to pathogenic factors, as well as accelerating the process of restoring the biological balance of soil, the possibility of using these preparations in agricultural practice is not yet fully examined [Kołodziejczyk, 2014; Zarzecka and Gugała, 2013; Zarzecka et al., 2017].

Therefore, the study aimed at identifying the impact of the $\mathrm{UG}_{\max }$ Soil Fertilizer on the presence of Streptomyces scabies on tubers of two edible potato cultivars was conducted.

\section{MATERIAL AND METHODS}

The field experiment was conducted in 20082010 in the Agricultural Experimental Station in Zawady, in the area of central Poland $\left(52^{\circ} 03^{\prime} \mathrm{N}\right.$; $22^{\circ} 3^{\prime} \mathrm{E}$ ), on the soil consisting of loamy sands. The characteristics of chemical properties of the soil are presented in Table 1.

The two-factor experiment was established using the split-plot system, in three replications. The examined factors included two medium early cultivars of edible potato - Satina and Typhoon, characterized by increased resistance to the common scab: Satina - grade 6.5, Typhoon - grade 6.0 on the scale of 1-9 [Plant Breeding and Acclimatization Institute, 2015].

Five methods of the $\mathrm{UG}_{\max }$ soil fertilizer application at different doses and dates:

Table 1. Chemical properties of the soil

\begin{tabular}{|l|c|c|c|}
\hline \multirow{2}{*}{ Specification } & \multicolumn{3}{c|}{ Years } \\
\cline { 2 - 4 } & 2008 & 2009 & 2010 \\
\hline Organic matter $\left[\mathrm{g} \cdot \mathrm{kg}^{-1}\right]$ & 15.4 & 17.8 & 18.1 \\
\hline Soil pH (1 M KCl) & 4.99 & 5.15 & 5.91 \\
\hline \multicolumn{4}{|c|}{ Content of available nutrients $\left[\mathrm{mg} \cdot \mathrm{kg}^{-1}\right]$} \\
\hline Phosphorus (P) & 90.6 & 95.9 & 73.5 \\
\hline Potassium (K) & 124.5 & 74.7 & 112.1 \\
\hline Magnesium (Mg) & 41.0 & 28.0 & 45.0 \\
\hline
\end{tabular}

1) Control object without $U G_{\max }$,

2) $U G_{\text {max }}$ applied to the soil before tuber planting at a dose of $1.0 \mathrm{dm}^{3} \cdot \mathrm{ha}^{-1}$,

3) $\mathrm{UG}_{\max }$ applied to the soil before tuber planting at a dose of $0.5 \mathrm{dm}^{3} \cdot \mathrm{ha}^{-1}$, when the height of plants is about $10-15 \mathrm{~cm}$, and in the flower buds making phase at a dose of $0.25 \mathrm{dm}^{3} \cdot \mathrm{ha}^{-1}$,

4) $U_{\max }$ before tuber planting at a dose of 1.0 $\mathrm{dm}^{3} \cdot \mathrm{ha}^{-1}$ and when the height of plants is about $10-15 \mathrm{~cm}$ and in the flower buds making phase at a dose of $0.5 \mathrm{dm}^{3} \cdot \mathrm{ha}^{-1}$,

5) $\mathrm{UG}_{\max }$ when the height of plants is about 10$15 \mathrm{~cm}$ and in the flower buds making phase at a dose of $0.5 \mathrm{dm}^{3} \cdot \mathrm{ha}^{-1}$. The Soil Fertilizer was dissolved in $300 \mathrm{dm}^{3}$ of water per 1 hectare.

The $\mathrm{UG}_{\max }$ Soil Fertilizer is a compost extract containing a vaccine of soil microorganisms. It consists of yeast, lactic acid bacteria, photosynthetic bacteria, Azotobacter spp., Pseudomonas spp., Actinomycetes, as well as macro- and microelements: potassium $\left(3500 \mathrm{mg} \cdot \mathrm{dm}^{3}\right)$, nitrogen $\left(1200 \mathrm{mg} \cdot \mathrm{dm}^{3}\right)$, sulphur $\left(1000 \mathrm{mg} \cdot \mathrm{dm}^{3}\right)$, phosphorus $\left(500 \mathrm{mg} \cdot \mathrm{dm}^{3}\right)$, sodium $\left(200 \mathrm{mg} \cdot \mathrm{dm}^{3}\right)$, magnesium $\left(100 \mathrm{mg} \cdot \mathrm{dm}^{3}\right)$, zinc $\left(20 \mathrm{mg} \cdot \mathrm{dm}^{3}\right)$, manganese $\left(0.3 \mathrm{mg} \cdot \mathrm{dm}^{3}\right)$ [Kołodziejczyk, 2014].

In autumn, prior to the establishment of the experiment, manure was applied at a dose of 25 $\mathrm{t} \cdot \mathrm{ha}^{-1}$, as well as mineral fertilization $(\mathrm{P}-39.6$, $\left.\mathrm{K}-112.0 \mathrm{~kg} \cdot \mathrm{ha}^{-1}\right)$, and during spring - nitrogen fertilization $\left(\mathrm{N}-90 \mathrm{~kg} \cdot \mathrm{ha}^{-1}\right)$. The assessment of infestation with common scab was performed directly after the harvest; on 100 randomly collected tubers from each experiment object (45 tests). The percentage of infested tubers was identified, as well as the average level of infestation of the sample and the average level of infestation of infested tubers on the scale of 1-9, where 9 means healthy tubers (no lesions), 1 - more than $50 \%$ of the surface area affected by the scab [Roztropowicz et al., 1999].

The test results were prepared statistically using variance analysis, and the significance of the differences was assessed using the Tukey's test, at the significance level of $\mathrm{p}=0.05$.

The weather conditions during the experiment were diverse (Table 2). In 2008, the air temperature was similar to the temperature in the multiannual period $\left(14.7^{\circ} \mathrm{C}\right)$ and rainfall was distributed evenly. In 2009, the air temperature and rainfall exceeded the average multiannual sum and were spread irregularly. The plant-growing season of potato in 2010 was the warmest and the most humid. 


\section{RESULTS AND DISCUSSION}

The analysis of the average three-year study results showed that the percentage of tubers with the symptoms of Streptomyces scabies (Table 3), the average level of tuber infestation (Table 4), as well as the average level of sample infestation (Table 5) depended on the method of the $\mathrm{UG}_{\max }$ Soil Fertilizer application, as well as the cultivar and the weather conditions during the study. In the conducted experiment, the average percentage of tubers with symptoms of Streptomyces scabies was $8.70 \%$, the average level of tuber infestation was 6.43 , and the level of sample infestation was 8.65, on a 9-point scale (Tables 3 and 4, 5).

The treatments conducted using the $\mathrm{UG}_{\max }$ preparation substantially reduced the occurrence of common scab on tubers of the potato cultivars being grown, as compared to the control object (where the $\mathrm{UG}_{\max }$ preparation was not applied). The share of tubers with symptoms of common scab was smaller on objects 4 and 3 (5.7 and 6.0\%, on average), where the $\mathrm{UG}_{\text {max }}$ preparation was applied three times (applied to soil before planting tubers, then when the height of plants was about $10-15 \mathrm{~cm}$, and in the flower buds making phase) (Table 3).
The research of Zarzyńska [2011] and Kowalska [2016] also showed that the treatments with the use of microbiological preparations reduced the development of potato diseases, regardless of the applied product and the form of its application. On the other hand, Jeske et al. [2015] did not prove the influence of the $\mathrm{UG}_{\max }$ preparation on the infestation of tubers with Streptomyces scabies. However, in the opinion of the authors, high air humidity was a factor limiting the disease's development.

The share of tubers with the symptoms of common scab was smaller in the Satina cultivar - on average by $15.40 \%$, than in the Typhoon cultivar - on average by $2.00 \%$ (Table 3 ). The Satina cultivar was also characterized by lower level of tuber infestation than in the case of the Typhoon cultivar. On the scale of 1-9, this value, amounted to: Satina - 5.37 and Typhoon - 7.49 (Table 4), respectively for the cultivar. The diverse reaction of potato cultivars to the common scab infestation was also proven by Hiltunen [2005] and Lambert [2006]. On the other hand, Jankowska and Lutomirska [2013], when examining 125 potato genotypes of different maturity classes, proved substantially larger infestation of tubers with Streptomyces scabies in very early and early cultivars.

Table 2. Air temperature and rainfall in the vegetation period of potato in 2008-2010 at the Zawady Meteorological Station

\begin{tabular}{|c|c|c|c|c|c|c|c|c|}
\hline \multirow{2}{*}{ Months } & \multicolumn{4}{|c|}{ Air temperature $\left({ }^{\circ} \mathrm{C}\right)$} & \multicolumn{5}{c|}{ Rainfall $(\mathrm{mm})$} \\
\cline { 2 - 11 } & $1987-2000$ & 2008 & 2009 & 2010 & $1987-2000$ & 2008 & 2009 & 2010 \\
\hline IV & 7.8 & 9.1 & 10.3 & 8.9 & 38.6 & 28.2 & 8.1 & 10.7 \\
\hline V & 12.5 & 12.7 & 12.9 & 14.0 & 44.1 & 85.6 & 68.9 & 93.2 \\
\hline VI & 17.2 & 17.4 & 15.7 & 17.4 & 52.4 & 49.0 & 145.2 & 62.6 \\
\hline VII & 19.2 & 18.4 & 19.4 & 21.6 & 49.8 & 69.8 & 26.4 & 77.0 \\
\hline VIII & 18.5 & 18.5 & 17.7 & 19.8 & 43.0 & 75.4 & 80.9 & 106.3 \\
\hline IX & 13.1 & 12.2 & 14.6 & 11.8 & 47.3 & 63.4 & 24.9 & 109.9 \\
\hline IV-IX & 14.7 & 14.7 & 15.1 & 15.6 & 275.2 & 371.4 & 354.4 & 459.7 \\
\hline
\end{tabular}

Table 3. Share of tubers with Streptomyces scabies symptoms depending on the cultivars and methods of application of $\mathrm{UG}_{\max }[$ in \%]

\begin{tabular}{|c|c|c|c|}
\hline \multirow{2}{*}{ Experimental factor } & \multicolumn{2}{|c|}{ Cultivar } & \multirow{2}{*}{ Mean } \\
\hline & Satina & Typhoon & \\
\hline 1. Control object - without UG ${ }_{\max }$ & 24.20 & 4.50 & 14.40 \\
\hline 2. $U_{\max } 1.0+0 \mathrm{dm}^{3} \cdot \mathrm{ha}^{-1}$ & 14.40 & 1.60 & 8.00 \\
\hline 3. $\mathrm{UG}_{\max } 0.5+0.25+0.25 \mathrm{dm}^{3} \cdot \mathrm{ha}^{-1}$ & 10.80 & 1.10 & 6.00 \\
\hline 4. $\mathrm{UG}_{\max } 1.0+0.25+0.25 \mathrm{dm}^{3} \cdot \mathrm{ha}^{-1}$ & 10.50 & 0.90 & 5.70 \\
\hline 5. $U G_{\max } 0+0.5+0.5 \mathrm{dm}^{3} \cdot \mathrm{ha}^{-1}$ & 17.10 & 1.90 & 9.50 \\
\hline Mean & 15.40 & 2.00 & 8.70 \\
\hline \multirow{2}{*}{\multicolumn{3}{|c|}{$\begin{array}{l}\text { LSD }_{0.05}: \text { Cultivars } \\
\text { Methods }\end{array}$}} & 2.20 \\
\hline & & & 2.90 \\
\hline \multicolumn{3}{|l|}{ Cultivars $x$ methods } & 2.90 \\
\hline
\end{tabular}

LSD - least significant difference 
Table 4. Average level of tuber infestation by Streptomyces scabies [scale 1-9] depending on the cultivars and methods of application of $\mathrm{UG}_{\max }$

\begin{tabular}{|l|c|c|c|}
\hline \multirow{2}{*}{ Experimental factor } & \multicolumn{2}{c|}{ Cultivar } & \multirow{2}{*}{ Mean } \\
\cline { 2 - 4 } & Satina & Typhoon & 5.31 \\
\hline 1. Control object - without $\mathrm{UG}_{\max }$ & 4.25 & 6.37 & 6.67 \\
\hline 2. $\mathrm{UG}_{\max } 1.0+0 \mathrm{dm}^{3} \cdot \mathrm{ha}^{-1}$ & 5.77 & 7.56 & 6.68 \\
\hline 3. $\mathrm{UG}_{\max } 0.5+0.25+0.25 \mathrm{dm}^{3} \cdot \mathrm{ha}^{-1}$ & 5.58 & 7.78 & 6.89 \\
\hline 4. $\mathrm{UG}_{\max } 1.0+0.25+0.25 \mathrm{dm}^{3} \cdot \mathrm{ha}^{-1}$ & 5.77 & 8.00 & 6.61 \\
\hline $5 . \mathrm{UG}_{\max } 0+0.5+0.5 \mathrm{dm}^{3} \cdot \mathrm{ha}^{-1}$ & 5.47 & 7.74 & 6.43 \\
\hline Mean & 5.37 & 7.49 & 0.35 \\
\hline LSD $_{0.05}$ : Cultivars & & & 0.80 \\
Methods & & & n.s. \\
\hline Cultivars x methods & & \\
\hline
\end{tabular}

LSD - least significant difference; n.s. - not significant

Table 5. Average level of sample infestation by Streptomyces scabies [scale 1-9] depending on the study years and methods of application of $\mathrm{UG}_{\max }$

\begin{tabular}{|c|c|c|c|c|}
\hline \multirow{2}{*}{ Experimental factor } & \multicolumn{3}{|c|}{ Year } & \multirow{2}{*}{ Mean } \\
\hline & 2008 & 2009 & 2010 & \\
\hline 1. Control object - without $\cup_{\max }$ & 8.22 & 8.15 & 8.63 & 8.33 \\
\hline 2. $\mathrm{UG}_{\max } 1,0+0 \mathrm{dm}^{3} \cdot \mathrm{ha}^{-1}$ & 8.67 & 8.60 & 8.78 & 8.68 \\
\hline 3. $\mathrm{UG}_{\max } 0,5+0,25+0,25 \mathrm{dm}^{3} \cdot \mathrm{ha}^{-1}$ & 8.71 & 8.74 & 8.91 & 8.79 \\
\hline 4. $\cup_{\max } 1,0+0,25+0,25 \mathrm{dm}^{3} \cdot \mathrm{ha}^{-1}$ & 8.83 & 8.78 & 8.72 & 8.78 \\
\hline 5. $U_{\max } 0+0,5+0,5 \mathrm{dm}^{3} \cdot \mathrm{ha}^{-1}$ & 8.52 & 8.55 & 8.88 & 8.65 \\
\hline Mean & 8.59 & 8.56 & 8.79 & 8.65 \\
\hline $\begin{array}{l}\mathrm{LSD}_{0.05}: \text { Years } \\
\text { Methods } \\
\text { Years } x \text { methods }\end{array}$ & & & & $\begin{array}{l}\text { n.s. } \\
0.17 \\
0.29\end{array}$ \\
\hline
\end{tabular}

LSD - least significant difference; n.s. - not significant

Table 6. Infestation of potato tubers by Streptomyces scabies in the study years [in \% and on a scale of 1-9]

\begin{tabular}{|l|c|c|c|c|c|}
\hline \multicolumn{1}{|c|}{ Specification } & \multicolumn{3}{c|}{ Year } & \multirow{2}{*}{ Mean } & \multirow{2}{*}{ LSD $_{0.05}$} \\
\cline { 2 - 5 } & 2008 & 2009 & 2010 & & 3.4 \\
\hline Procentage of infested tubers & 10.80 & 10.00 & 5.40 & 8.70 & 3.4 \\
\hline $\begin{array}{l}\text { Average level of tuber infestation by Streptomyces } \\
\text { scabies (scale 1-9) }\end{array}$ & 5.95 & 6.30 & 7.04 & 6.43 & 0.54 \\
\hline Average level of sample infestation (scale 1-9) & 8.59 & 8.56 & 8.79 & 8.65 & n.s. \\
\hline
\end{tabular}

LSD - least significant difference; n.s. - not significant

The experiment demonstrated that the average percentage of tubers with symptoms of Streptomyces scabies, the average level of tuber infestation, and the level of sample infestation depended upon the meteorological conditions in the study years (Tables 5 and 6). The lowest intensity of the disease occurred in 2010, when the air temperatures during the potato vegetation period (May - August) were higher than the multiannual average temperatures. The vegetation season in 2010 was also characterized by high air humidity (Table 2). These results are consistent with the research of other authors [Lutomirska,
2008; Jankowska and Lutomirska, 2013; Kapsa and Gawińska-Urbanowicz, 2013], who proved that the significant factor restricting the development of Streptomyces scabies on potato tubers is high air temperature and high humidity during the plant vegetation.

\section{CONCLUSIONS}

The $\mathrm{UG}_{\max }$ Soil Fertilizer, applied at different doses and dates, limited the percentage of tubers with the symptoms of Streptomyces scabies, the 
level of tuber infestation, and the level of infested tubers, as compared to the tubers harvested from the control object, where the $\mathrm{UG}_{\max }$ preparation was not applied.

The share of tubers with the symptoms of the common scab and the level of tuber infestation was smaller in the case of the Satina cultivar than the Typhoon cultivar.

The presence of Streptomyces scabies and the level of tuber infestation were mainly determined by the weather conditions prevailing during the potato vegetation period. High air temperature and high humidity reduced the development of the pathogen.

\section{Acknowledgements}

The results of the research carried out under the research theme number 214/04/S were financed from the science grant granted by the Ministry of Science and Higher Education.

\section{REFERENCES}

1. Atiq M., Khalid A.R., Hussian W., Nawaz A., Asad S., Ahmad T.M. 2013. Genetic potential of potato germplasm against common scab disease caused by Streptomyces scabies. Pakistan Journal of Phytopathology, 25(1), 27-30.

2. Baranowska A., Zarzecka K., Gugała M., Mystkowska I. 2017. Cntents of zinc, copper and manganese in potato tubers depending on the ways of application of the soil fertilizer $\mathrm{UG}_{\max }$. Journal of Ecological Engineering, 18(1), 99-106.

3. Borodynko N., Dobosz R., Dworzańska D., Erlichowski T., Jakubowska M., Klejdysz T., Kozłowski J., Kubasik W., MaćkowiakSochacka A., Mrówczyński M., Osowski, J, Strażyński P., Węgorek P., Wójtowicz A., Zamojska J. 2016. Potato protection indicator manual. Institute of Plant Protection - National Research Institute. Poznań.

4. Chater K.F., Biró S., Lee K.J., Palmer T., Schrempf H. 2010. The complex extracellular biology of Streptomyces. Federation of European Microbiological Societies. Microbiology Reviews, 34(2), 171-198.

5. Hamouz K., Lachman J., Hejtmánková K., Pazderů K., Čížek M., Dvořák P. 2010. Effect of natural and growing conditions on the content of phenolics in potatoes with different flesh colour. Plant, Soil and Environment, 56, 368-374.

6. Hiltunen L.H., Weckman A., Ylhainen A., Rita H., Richter H., Valkonen J.P.T. 2005. Responses of potato cultivars to the common scab pathogens, Streptomyces scabies and S. turgidicabies. Annals of Applied Biology, 146, 395-403.

7. Jankowska J., Lutomirska B. 2013. Environmental and genotypic variation of Streptomyces ssp. occurrence on tubers of advanced potato breeding materiale. Progress in Plant Protection/Postępy w Ochronie Roślin, 53(3), 538-544.

8. Jeske M., Pańka D., Wichrowska D. 2015. Effect of chemical protection, organic fertilization and UGmax soil conditioner on health status of potato tubers. Progress in Plant Protection/Postępy w Ochronie Roślin, 55(1), 92-97.

9. Kapsa J., Gawińska-Urbanowicz H. 2013. Disease incidence on potato inPolandin the years 2009-2012. Progress in Plant Protection/Postępy w Ochronie Roślin, 53(1), 545-551.

10. Kołodziejczyk M. 2014. Effectiveness of nitrogen fertilization and application of microbial preparations in potato cultivation. Turkish Journal of Agriculture and Forestry, 38, 299-310.

11. Kowalska J. 2016. Effect of fertilization and microbiological bio-stimulators on healthiness and yield of organic potato. Progress in Plant Protection/Postępy w Ochronie Roślin, 56(2), 230-235.

12. Lambert D.H., Reeves A.F., Goth R.W., Grounds G.S., Giggie E.A. 2006. Relative susceptibility of potato varieties to Streptomyces scabiei and S. acidiscabies. American Journal of Potato Research, 83, 67-70.

13. Leiminger J., Frank M., Wenk C., Poschenrieder G., Kellermann A., Schwarzfischer A. 2013. Distribution and characterization of Streptomyces species causing potato common scab in Germany. Plant Pathology, 62, 611-623.

14. Lerat S., Simao-Beaunoir A.M., Beaulieu C. 2009. Genetic and physiological determinants of Streptomyces scabies pathogenicity. Molecular Plant Pathology, 10(5), 579-85.

15. Loria R., Bukhalid R.A., Fry B.A., King R.R. 1997. Plant pathogenicity in the genus treptomyces. Plant Disease, 81, 836-846.

16. Loria R., Coombs J., Yoshida M., Kers J., Bukhalid R. 2003. A paucity of bacterial root diseases: Streptomyces succeeds where others fail. Physiological and Molecular Plant Pathology, 62, 65-72.

17. Loria R., Kers J., Joshi M. 2006. Evolution of plant pathogenicity in Streptomyces. Annual Review of Phytopathology, 44, 469-487.

18. Lutomirska B. 2008. The influence of meteorological factors on tuber infection with common scab. Progress in Plant Protection/Postępy w Ochronie Roślin, 48(1), 216-220.

19. Plant Breeding and Acclimatization Institute - National Research Institute, 2015. Characteristics of 
the National Potato Cultivar Register. Issue XVIII. Jadwisin.

20. Roztropowicz S., Czerko Z., Głuska A., Goliszewski W., Gruczek T., Lis B., Lutomierska B., Nowacki W., Rykaczewska K., Sowa-Niedziałkowska G., Szutkowska M., Wierzejska-Bujakowska A., Zarzyńska K., Zgórska K. 1999. Methodology of observations, measurements and sampling in agrotechnical experiments with potato. Plant Breeding and Acclimatization Institute Radzików, Branch in Jadwisin.

21. Tegg R.S., Gill W.M., Thompson H.K., Davies N.W., Ross J.J., Wilson C.R. 2008. Auxin-induced resistance to common scab disease of potato linked to inhibition of thaxtomin A toxicity. Plant Disease, 92, 1321-1328.

22. Waterer D.R. 2002. Management of common scab of potato using planting and harvest dates. Canadian Journal of Plant Science, 82, 185-189.

23. Wróbel S. 2003. Infection of seed potato tubers by common scab and black scurf depending on treat- ments used in seed production. Biuletyn Instytutu Hodowli i Aklimatyzacji Roślin, 228, 283-289.

24. Zarzecka K., Gugała M. 2013. The effects of soil fertilizer UGmax on yield of potato tubers and its structure. Biuletyn Instytutu Hodowli i Aklimatyzacji Roślin, 267, 107-112.

25. Zarzecka K., Gugała M., Baranowska A., Dołęga H., Sikorska A. 2016. Concentrations of copper, zinc and manganese in potato tubers under the influence of herbicides. Journal of Elementology, 21(1), 259-267.

26. Zarzecka K., Gugała M., Mystkowska I., Baranowska A., Sikorska A. 2017. Sensory quality of potato tubers depending on UGmax application. Fragmenta Agronomica, 34(1), 117-125.

27. Zarzyńska K. 2011. The influence of some agrotechnical factors on marketable quality of potato grown under organic farming system. Bulletin of Plant Breeding and Acclimatization Institute, 259, 243-250. 